
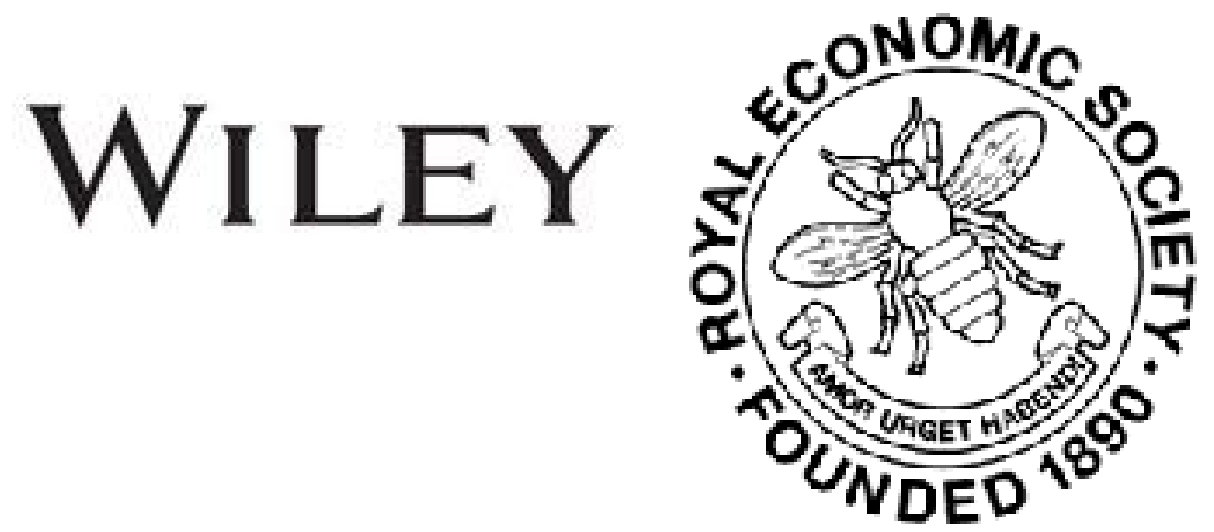

\title{
Competition as it Affects Banking
} Author(s): Francis E. Steele

Source: The Economic Journal, Vol. 3, No. 12 (Dec., 1893), pp. 637-643

Published by: Wiley on behalf of the Royal Economic Society

Stable URL: http://www.jstor.org/stable/2956191

Accessed: 26-06-2016 20:40 UTC

Your use of the JSTOR archive indicates your acceptance of the Terms \& Conditions of Use, available at

http://about.jstor.org/terms

JSTOR is a not-for-profit service that helps scholars, researchers, and students discover, use, and build upon a wide range of content in a trusted digital archive. We use information technology and tools to increase productivity and facilitate new forms of scholarship. For more information about JSTOR, please contact support@jstor.org.

Wiley, Royal Economic Society are collaborating with JSTOR to digitize, preserve and extend access to The Economic Journal 


\section{COMPETITION AS IT AFFECTS BANKING.}

Although it may safely be said that the subject of competition, in its general bearing, has been so fully discussed that it is almost threadbare, it may be asserted with equal confidence that the study of the effects of competition on individual branches of commerce has been by no means exhausted, but still affords in many directions ample scope for further inquiry. That this should be so is of course no slur upon economists. They concern themselves generally, and legitimately, with broad principles and tendencies at large, taking note of particular businesses only in so far as these serve to illustrate general conclusions. There are, however, some few departments of business so closely intertwined with the social and commercial fabric that any great influence at work in them becomes a matter of general concern. The business of banking, as this year's events in Australia have unpleasantly reminded us, comes distinctly within this category. Interests so many and so varied are dependent upon it that no tendencies affecting banking institutions can be regarded with indifference by any class of the community; and as the Duke of Argyll has recently descanted, not entirely without cause, upon the hitherto neglected elements of Political Economy in general, one may perhaps be allowed, at less length be it hoped, but with not less reason, to glance at a few results of the comparatively 'neglected element' of competition as it affects the department of banking in particular.

To deal with all the aspects of even this narrower branch of the subject would require more space than is at my disposal; I propose therefore to confine my remarks chiefly to competition from within; that is to say, as between the regular banks themselves, omitting any detailed reference to such competition from without as that of the Bank of England at one end of the scale and of savings banks, post office and trustee, at the other. One feels very much tempted, in view of the interest aroused by 
the Savings Banks Bill now before Parliament, to go into this latter question of the competition of savings banks. If one may judge from the views expressed by the influential deputation of bankers which waited upon the Chancellor of the Exchequer in the spring it is quite clear that the extension of the deposit limit proposed in the Bill was regarded by many bankers as constituting a form of competition likely to encroach appreciably upon general banking business, and as being specially unfair in that, while the private and joint-stock banks have only their own efforts to rely upon, the savings banks have behind them the prestige and the credit of the State. With all respect both to the constitution of the deputation and to the views expressed by its members, I venture to think it is quite open to question whether the passing of this debatable measure would have any appreciable effect upon the ordinary banking business of the country. The accounts likely to be transferred to the Post Office Savings Bank in consequence of an alteration of the annual limit from $£ 30$ to $£ 50$ are precisely those, whether current or deposit, which entail upon bankers a maximum of trouble for a minimum of profit; and the number of such accounts seems to have been greatly over-rated. One feels much disposed to adopt in this matter, with very slight modification, the useful phrase coined for quite another purpose by Cairnes, and to regard the savings banks and the regular banks of this country as 'non-competing groups,' each group discharging special functions of its own and scarcely trenching at all upon the legitimate sphere of the other. However this may be-and there is of course plenty of room for difference of opinion on the matter-the question of State-aided competition which this controversy opens up is too large to be more than touched upon here, and it will be well to pass on from what Mr. Swinburne would call ' the gulfs and estuaries' of the subject to the principal issue before us.

It may with advantage be suggested at the outset that, severe as the action of competition in the sphere of banking undoubtedly is, yet it is more limited than it is frequently assumed to be, and less keen in several respects than in many other businesses. To take an instance in one direction only, we know quite well that although theoretically there is nothing whatever to prevent the formation of new banks in this country, yet as a matter of fact there is very little likelihood of any such institutions, either private or joint-stock, being formed on any scale. In most businesses, the risk attendant upon a new undertaking is the risk of the promoters - they are the creditors, and the public are the 
debtors; but in banking the relations are to a large extent reversed, and the customers, especially in these days of limited liability and of reconstruction schemes, really divide the risks with the shareholders. As a consequence, existing banks, among themselves, enjoy what is practically a monopoly, and a very profitable one. They may dread each other, but need fear no antagonists beyond their own charmed circle. It is well to remember too that the competition between existing banks is limited in many directions by voluntary agreement, either explicit or tacit, as for instance in such matters as deposit rates, areas of operation, and mutual support in cases of emergency. It is true that some agreements of the character last referred to have proved ineffectual at the very time when they should have come into operation. The resolution, for example, passed by the Associated Banks of Victoria in March of the present year, in which it was agreed 'that the Associated Banks of Victoria will be ready to render financial assistance to each other, on such terms and to such extent as may seem justifiable to each other, if and when occasion arises,' proved in the event both misleading and inoperative; but instances to the contrary in our own country, though on a smaller scale, might be cited as a set-off. During recent credit disturbances in London, for instance, many cases have occurred in which bankers who have been offered lucrative and desirable accounts have made every effort to discountenance the transfer by assuring the would-be transferors of the groundlessness of their fears as to the stability of their own bank. This statement will probably not be credited by those readers of this journal who may still believe in Adam Smith's ' Scotchman inside every man,' and will be regarded by economists of the Ruskin School (if indeed they believe it at all) as merely an isolated instance of honour among thieves; but for its authenticity in a number of cases the writer can personally vouch.

But despite such limitations, inherent and self-imposed, the struggle for business between banks both at home and in the colonies is exceedingly keen, and is becoming increasingly so every year. Viewed from some standpoints this fact is as satisfactory as it is undeniable. The community at large, at any rate, has up to the present had little reason to complain. Through the rivalry of banks the difficulty of obtaining capital has been minimized, strong banks have become stronger, weaker institutions have been weeded out, lending rates have fallen, industry and enterprise have been fostered, and the evils which accompany monopoly in its various forms have been effectrally 
prevented. Not a few of the more satisfactory among the distinctive features of present-day banking are directly due to the same cause. The more frequent publication of accounts, the rapid growth of the branch system, the wider range of services now rendered as a matter of course by bankers to their customers, such features even, despite the seeming paradox, as the increase which has taken place within the last three years in cash reserves and in the amount invested by banks in first-class securities, have all been concurrent with, and in one sense largely the result of, the stronger growth of the competitive spirit. Illustrations of the beneficial effects of competition in these and other directions might easily be given, and will indeed readily occur to the minds of those engaged in the strife, but there is no necessity to enlarge upon this aspect of the matter. It is to its other aspect, the less satisfactory one, that attention most needs to be directed. We are in no danger of under-estimating the results of a healthy rivalry; even if we do under-estimate them no one is much the worse; the danger lies in ignoring the risks which that rivalry brings in its train, and in shutting our eyes to the fact, which is becoming more patent every day, that the boundary line between safe and doubtful banking methods may be only too easily overstepped. In this branch of Economics, as indeed in all other branches, the Law of Compensation asserts itself, and we need not therefore be surprised to find that the advantages here briefly touched upon, and others which have necessarily been left unnoticed, are not without a corresponding set-off. As even monopoly in banking has its redeeming features, so competition has its drawbacks, and it is to the consideration of a few of these that attention must now be directed.

Take as an illustration the great development of the branch movement which has been already incidentally referred to. The ample statistics available show that of late years the multiplication of branch banks has been exceedingly rapid; that not only has the actual number of offices in the United Kingdom greatly increased, but there are now far more branches in proportion to population than was the case even ten years ago, and that the growth of the branch system has been equally striking in some of our colonies and possessions. Up to a certain point this movement, both here and there, has resulted in almost unmixed good. At home it has brought banking facilities within the reach of all ; in the colonies it has enabled the banks, to the advantage of all concerned, to get in touch with the industries of outlying districts which the head offices by themselves could not possibly have 
reached. But there are signs in many directions that the movement is beginning to be overdone, and that we are getting 'overbranched.' In one of the suburbs of London there is a street in which, within a walk of ten minutes, there are to be found no fewer than seven branches of various banks; while in a neighbouring street there are three more, all engaged in the most active competition for business; and although this case is possibly a somewhat extreme one, it is indicative of a similar tendency in many other directions. In many districts a volume of business sufficient to yield a fair profit to one or two branches is keenly competed for by four or five. Of course in the first instance this is a matter which concerns only the shareholders of the institutions represented; the general public, looking on at the struggle, can say with Iago:-

' Now whether he kill Cassio, Or Cassio him, or each do kill the other, Every way makes my game.'

But in its later developments it threatens to become, and in some cases has actually become, a source of public danger, by the pressure brought to bear upon the branches to take doubtful business and to make advances upon unsuitable security. A customer asks for an advance upon security all very well in its way, but of a kind which a banker should not encourage, and under ordinary circumstances, would refuse. Knowing, however, that if he should refuse, the accommodation will probably be obtained elsewhere, he is disposed to recommend the authorities to grant the loan, and if this one transaction stood by itself no great harm would be done. But it is precisely by the repetition of this process that a bank finds itself overstocked with securities which it cannot realise, and so gets into difficulties. Why did the Australian banks during the much-canvassed land boom make such heavy advances at top prices on 'eligible city lots'? Certainly not on account of any preference for that particular form of security, but because they were bound to find some employment for the capital on which they were paying interest, and each bank feared that the accommodation which it might withhold would be accorded by its rivals. "The bank failures here,' says an Australian correspondent, 'are largely due to the ruinous competition which has been maintained by the banks to obtain new business. Money has been advanced in some cases without adequate security, and customers have been able to obtain advances at the top price of their securities. With 
the fall in prices the banks have had a serious deficit to face, and their only hope of continuing has been to suspend payment and reconstruct.' I do not for a moment suggest that banking in England has many features in common with banking in Australia before the collapse, nor would I of course be understood to object to the branch system in itself, but it appears to me that the supply of branches in many districts is too great in proportion to the demand, that the system is being too rapidly developed, and that this undue development must inevitably tend to bring about evils of the kind, if not the degree, of those which I have pointed out.

A result of excessive competition in banking which is more apparent, and therefore more generally acknowledged, is its effect upon banking reserves. Whatever functions a bank may undertake to perform for its customers, its first duty, both to them and to its shareholders, as well as to the public, is the maintenance of an adequate reserve. Yet who will venture to say that this duty is either fully recognised or satisfactorily performed? Despite the improvement which undoubtedly took place after the Baring collapse and the consequent warnings of Mr. Lidderdale and Mr. Goschen-an improvement, by the way, as much due to want of opportunity for profitable lending as to any enthusiasm for the canons of sound banking- 'banking up to the hilt' is still, with a few honourable exceptions, the order of the day. It was thought that the more frequent publication of accounts would help to remedy this defect, and no doubt it has done so, but what a light is thrown upon the value of these monthly statements when we read regularly in the daily papers on the first of each month that 'money was scarce yesterday owing to the calling in of loans by the banks in connection with their monthly balance sheets'; and for how many of our banks can a claim be made and sustained such as that put forward and justified by the Chairman of the London and Westminster at the last half yearly meeting, that the average daily amount of 'cash in hand' at that institution is in excess of the figures given in the monthly returns? It would of course be absurd to argue that a certain definite proportion of every bank's deposits should be retained in cash as a reserve. Everyone who knows anything about banking is well aware that the nature of the accounts of different concerns varies so much that a proportion sufficient in one case would be altogether inadequate in another; but the fact remains that in some instances the reserves kept cannot by any stretch of the imagination be regarded as satisfactory, and that 
the constant tendency to over-competition in the race for high dividends exerts an influence in direct opposition to the public welfare.

Other instances of scarcely less importance might be easily adduced, but the foregoing must suffice. So far from exhausting the subject, I have only touched upon the fringe of it, whether in regard to the nature of the rivalry between banks, or its limits; its advantages or its defects; but in dealing briefly with each of these divisions of the subject I have endeavoured to give illustrations which should be so far as possible typical or explanatory of the rest. Sufficient may possibly have been said to bear out the 'conclusion of the whole matter' at which the writer has arrived, that the growth of competition in banking will need to be closely watched and carefully regulated if it is not to be allowed seriously to impair the efficiency of the splendid mechanism, in the form of the banking system of this country, which it has done so much to develop and perfect.

Francis E. Steele 